\title{
Hidden Behind the Wall: West German State Building and the Emergence of the Iron Curtain
}

\author{
Sagi Schaefer
}

$\mathrm{I}$ $\mathrm{T}$ is widely accepted that the inter-German border was constructed by East German authorities to halt the emigration to the west, which had damaged the East German economy and undermined the East German state agencies' power. ${ }^{1}$ This article argues that this is an inaccurate understanding, which mistakenly treats perceptions and insights gained from studying the Berlin Wall as representative of the mostly rural border between East and West Germany. It emphasizes crucial transformations of frontier society during the 1950s, highlighting the important role of western as well as eastern policy in shaping them.

Cold-War perceptions and the captivating imagery of the Berlin Wall have for many years overdetermined the history of German division. For twenty-eight years, until November 1989, Berlin had been the most important icon of the Cold War, and the fall of the Berlin Wall remains the best-known marker of its end. ${ }^{2}$ It

This article is part of a dissertation project at Columbia University, titled "Ironing the Curtain: Border and Boundary Formation in Cold War Rural Germany." I wish to thank my adviser, Volker Berghahn, for his critical support and guidance throughout the project. I have benefited enormously from the comments on various versions of this text by Astrid M. Eckert, Bill McAllister, Brandon County, Edith Sheffer, Gil Eyal, Giuliana Chamedes, Istvan Deak, Jörg Echternkamp, Karen Barkey, Mark Mazower, Mari Webel, Reto Hofmann, Sara Doskow, Steve Wills, and Uri Shwed. The anonymous reviewers for Central European History also challenged me to clarify arguments and improve the coherence and readability of this article. I thank the participants of the European history seminar at Columbia University and my colleagues at the Institute for Social and Economic Research and Policy (ISERP) who have given me a chance to present previous versions of this text. I am especially indebted to Frank Biess for crucial support and generous engagement with this project. Tali Schaefer read many versions of this text and contributed tremendous editorial and content suggestions. Research for this article was supported by the Deutscher Akademischer Austausch Dienst (DAAD), Columbia University, the Whiting Foundation, and ISERP.

${ }^{1}$ For example, see Mary Fulbrook, The People's State: East German Society from Hitler to Honecker (New Haven, CT, and London: Yale University Press, 2005), 7; Corey Ross, Constructing Socialism at the Grass-Roots: The Transformation of East Germany, 1945-65 (New York: St. Martin's Press, 2000); Jürgen Ritter and Peter Joachim Lapp, Die Grenze. Ein deutsches Bauwerk (Berlin: Links, 2006), 19; Dietmar Schultke, "Keiner kommt durch." Die Geschichte der innerdeutsche Grenze 1945-1990 (Berlin: Aufbau Taschenbuch Verlag, 1999), 33.

${ }^{2}$ Patrick Major makes a similar point in Patrick Major, Behind the Berlin Wall: East Germany and the Frontiers of Power (Oxford and New York: Oxford University Press, 2010), 1. For example, a recent volume dealing with 1989 as a global transformative year is titled "The Fall of the Berlin Wall." 
is no wonder, then, that scholars have studied the Berlin Wall more extensively than any other part of the inter-German border as the symbol for the division of Germany. ${ }^{3}$

Following Peter Sahlins, this article emphasizes the interrelations between processes of border formation and state building. Sahlins studied the evolution of the border between Spain and France as a process of state building and demonstrated that political borders can give rise to parallel changes in identification patterns. His work has inspired the study of other borders and periods, but until recently has had little effect on the study of the interGerman border. ${ }^{4}$ Besides fences, walls, mines, bunkers, and watchtowers, our knowledge about the inter-German border outside Berlin has been limited to government decisions and their enforcement, and, of course, to dramatic escape attempts. After the collapse of the border in 1989, a stream of memoirs and personal narratives emerged, opening a window to the experiences of life along the border. ${ }^{5}$ In the past decade, scholars have begun to analyze dimensions of social and cultural transformation involved

Jeffrey A. Engel, The Fall of the Berlin Wall: The Revolutionary Legacy of 1989 (Oxford and New York: Oxford University Press, 2009).

${ }^{3}$ The list of studies of divided Berlin and different aspects of life of the city leading to or emanating from the building of the Wall is too long to recount here. Some examples from recent years include Frank Roggenbuch, Das Berliner Grenzgängerproblem (Berlin and New York: Walter de Gruyter, 2008); Hope M. Harrison, Driving the Soviets up the Wall: Soviet-East German Relations, 1953-1961 (Princeton, NJ: Princeton University Press, 2003); Hans-Hermann Hertle, Konrad H. Jarausch, and Christoph Kleßmann, eds., Mauerbau und Mauerfall. Ursachen-Verlauf-Auswirkungen (Berlin: Links, 2002); Major, Behind the Berlin Wall; Edgar Wolfrum, Die Mauer. Geschichte einer Teilung (Munich: C. H. Beck, 2009).

${ }^{4}$ Peter Sahlins, Boundaries: The Making of France and Spain in the Pyrenees (Berkeley and Los Angeles, CA: University of California Press, 1989). I share this critique of existing studies of the inter-German border with Edith Sheffer. See her summary of the deficiencies of these studies in Edith Sheffer, "Burned Bridge: How East and West Germans Made the Iron Curtain" (Ph.D. diss., University of California, Berkeley, 2008), 9-10. Patrick Major also criticizes studies of the inter-German border for overly emphasizing physical aspects of the border. See Major, Behind the Berlin Wall, 6-7. Gerhard Sälter, Grenzpolizisten. Konformität, Verweigerung und Repression in der Grenzpolizei und den Grenztruppen der DDR 1952 bis 1965 (Berlin: Christoph Links Verlag, 2009), 2, and the authors cited in footnote 3 also argue that until now there was an overemphasis in research on these aspects of the border. For some recent examples, see Klaus-Dieter Baumgarten and Peter Freitag, eds., Die Grenzen der DDR. Geschichte, Fakten, Hintergrunde (Berlin: Edition-Ost, 2005); Schultke, "Keiner kommt durch"; Peter Joachim Lapp, Gefechtsdienst im Frieden-Das Grenzregime der DDR (Bonn: Bernard \& Grafe, 1999); Axel Janowitz, "Die Geschichte der innerdeutsche Grenze," in Grenze-mitten im Deutschland, ed. Grenzlandmuseum Eichsfeld e.V. (Heiligenstadt: Cordier, 2002), 25-42.

${ }^{5}$ Most of these narratives were published in edited volumes. For some examples, see Heiko Steffens, Birger Ollrogge, and Gabriela Kubanek, eds., Lebensjahre im Schatten der deutschen Grenze (Opladen: Leske + Budrich Verlag, 1990); Rudolf Zietz, Erlebnisse an der Grenze im Harz (Duderstadt: Mecke, 2003); Andreas Hartmann and Sabine Doering-Manteuffel, eds., Grenzgeschichten. Berichte aus dem deutschen Niemandsland (Frankfurt am Main: S. Fischer, 1990); Joachim S. Hohmann and Gerhard Grischok, eds., Grenzland Rhön (Hünfeld: Rhön Verlag, 1997); Roman Grafe, ed., Die Grenze durch Deutschland. Eine Chronik von 1945 bis 1990 (Berlin: Siedler, 2002). 
in border construction more systematically. Such studies question many aspects of the historical perception of this border and are gradually transforming it. ${ }^{6}$

Studying the interlaced effects of state building and border formation preceding the construction of the Berlin Wall, this article contributes to this trend by demonstrating that the division of Germany was well under way by 1961, driven significantly by western policies and initiatives. The article contends that scholars have not assigned sufficient causality to these processes because of the greater drama and visibility of events in Berlin. Despite the very important contribution of these processes to the division of Germany, they remain, in other words, "hidden behind the Wall."

The Berlin Wall was constructed in August 1961 by the Soviet-backed government of the German Democratic Republic (GDR), primarily to stop East Germans from moving to the west. ${ }^{7}$ Viewing the history of the entire interGerman border as having been constructed for similar causes fitted Cold-War ideological battles. It was easy to uphold this view because the visible, physical construction of the border was mostly initiated by East Germany. ${ }^{8}$ Such

\footnotetext{
${ }^{6}$ For some of the most recent works, see Maren Ullrich, Geteilte Ansichten. Erinnerungslandschaft deutsch-deutsche Grenze (Berlin: Aufbau Verlag, 2006), which analyzes memorial culture along the inter-German border through the years of division and unification. Sheffer, "Burned Bridge," is an extremely rich micro-study of the development of this border between two towns that emphasizes the agency of frontier residents in this process. The first publication out of this excellent dissertation was Edith Sheffer, "On Edge: Building the Border in East and West Germany," Central European History 40 (2007): 307-339. As this article is being prepared for print, the book based on her dissertation is scheduled to appear in several months. See Edith Sheffer, Burned Bridge: How East and West Germans Made the Iron Curtain (Oxford University Press, forthcoming 2011). Astrid M. Eckert of Emory University is working on a project to analyze different aspects of West German state and nation building as they took place along the inter-German border. She began this project with an investigation of border tourism in the FRG. See Astrid M. Eckert, "'Greetings from the Zonal Border"': Tourism to the Iron Curtain in West Germany," Zeithistorische Forschung/Studies in Contemporary History 8, no. 1 (2011): 9-36. Jason Johnson is preparing a dissertation at Northwestern University with the working title "Dividing Mödlareuth: The Incorporation of Half a German Village into the GDR Regime, 1945-1989." These projects, and my own, owe a lot to the late Daphne Berdahl's fascinating anthropological study of the village of Kella in the transformative years of German unification. Daphne Berdahl, Where the World Ended: Reunification and Identity in the German Borderland (Berkeley and Los Angeles, CA: University of California Press, 1999). See also the report from a recent workshop on the history of the inter-German border that brings together some of the people mentioned above and others and suggests that the transformation of perspective in studying the inter-German border is gathering momentum: Tagungsbericht Grenze-Konstruktion Realität Narrative, June 24-26, 2010, Hannover, in H-Soz-u-Kult, July 28, 2010, http://hsozkult. geschichte.hu-berlin.de/tagungsberichte/id=3213.

${ }^{7}$ See Thomas Lindenberger, "Diktatur der Grenze(n). Die eingemauerte Gesellschaft und ihre Feinde," in Mauerbau und Mauerfall, ed. Hertle, Jarausch, and Kleßmann, 203.

${ }^{8}$ See an example of assigning all the initiative in the division of Germany to the east based on looking at the most visible steps and interpreting them as having exclusively internal eastern causes in Thomas Lindenberger, “'Zonenrand,' 'Sperrgebiet' und 'Westberlin.' Deutschland als Grenzregion des Kalten Kriegs," in Teilung und Integration. Die doppelte deutsche Nachkriegsgeschichte als wissenschaftliches und didaktisches Problem, ed. Christoph Kleßmann and Peter Lautzas (Bonn: Bundeszentrale für politische Bildung, 2005), 102-104.
} 
reasoning, though, confuses result with intention, ignores change over time, and neglects to look outside Berlin. Through sixteen years after the end of World War II, the social division of Germany and the physical construction of the border between west and east progressed under different conditions and served different goals. The first major physical construction of the border initiated by eastern state agencies in summer 1952 was partly a reaction to western policies. It was aimed, as shown below, as much toward the west, in an attempt to force recognition of the GDR, as it was toward East German citizens.

This article analyzes the impact of the western "claim to exclusive representation of the German people" (Alleinvertretungsanspruch) on the formation of boundaries between East and West Germany. It shows that the western insistence on diplomatically isolating the German Democratic Republic, with the declared aim of preserving German unity, actually contributed to the emergence of physical and political demarcations as well as long-lasting social divisions. These changes emerged gradually, not as a direct product of conscious efforts by any one actor. The article shows how policies connected with the western claim to exclusive representation and eastern state agencies' reactions to it worked to further the physical build-up of the border and to undermine regional, crossborder coordination and identification.

The article establishes these arguments through the analysis of bordercrossing relations in a well-integrated region with a tradition of strong regional identification, which was split by the inter-German border. The Eichsfeld region in central Germany had been an enclosed Catholic enclave in a Protestant-dominated region ever since the Counter-Reformation. It was divided between Hanover and Saxony in the post-Napoleonic order, and the borderline then drawn was adopted as the dividing line between two Prussian provinces in united Germany. Eventually, with little change, this became the demarcation line between the Soviet and the British and U.S. zones in $1945 .{ }^{9}$ Pre-1945 divisions of the region did not undermine the strong cohesion of this regional community as evident by the thick kinship networks, regional organizations, pilgrimages, and celebrations that bound Eichsfelder and brought them together across state and province borders.

The case studies analyzed in this article show how local politicians from the West and East German parts of the Eichsfeld used shared traditions to circumvent western authorities' prohibition of official border-crossing meetings. Genuine popular interest, local initiative, and massive participation created the opportunity and gave rise to lively border-crossing cultural exchange. Western state agencies

\footnotetext{
${ }^{9}$ For details about the first division of the Eichsfeld in 1815-16, see Ulrich Hussong, "Die Teilung des Eichsfeldes im Jahre 1815," Eichsfeld Jahrbuch (1993): 5-92; Peter Aufgebauer, "Geschichte einer Grenzlandschaft," in Das Eichsfeld. Ein deutscher Grenzraum, ed. Peter Aufgebauer et al. (Duderstadt: Mecke, 2002), 75-76.
} 
approved border-crossing visits and meetings that were couched in this context. For several years during the second half of the 1950s, officials from both sides of the border met and engaged in complicated negotiations. These local administrators shared the wish to promote local economic, cultural, and other interests, but they also served the interests and priorities of state organizations, which eventually doomed their efforts. State agencies, engulfed in the battle over recognition of the GDR, circumscribed the negotiations in ways that led to their inevitable failure. This failure taught the administrators and frontier residents involved that the determination of central state authorities to uphold dividing strategies was stronger than the ties that bound Eichsfelder together.

All along the inter-German border, frontier residents and administrations came together during the 1950s to seek ways to overcome difficulties caused by the emerging border. Edith Sheffer analyzed a similar series of meetings and negotiations between western and eastern frontier administrators in her dissertation, for example. ${ }^{10}$ The general contours of the affair in the region she studied were quite similar to those analyzed in this article: frontier administrators met and talked throughout the period but could not overcome the dynamics of division. The analysis of cooperation attempts in the Eichsfeld presented in this article demonstrates that the regional border-crossing negotiations failed before the building of the Berlin Wall and their failure was not a result of changes in East German policy. I argue that the dramatic changes of 1961 have concealed the effect of division processes during the 1950s and the less visible factors behind them.

This article contends that many players at many levels shaped the Cold War. The realities and the meanings of the Iron Curtain and the Cold War were not produced exclusively in Moscow and Washington. Nor did they grow entirely out of the everyday actions of frontier populations. Individuals, families, and communities, and all levels of state organizations from district and county authorities to states and superpowers were involved in creating the Cold War. The division of Germany and Europe transformed the lives of many millions and radically influenced the perceptions of generations worldwide. A major source for these momentous transformations were the interactions between these different elements of society. Along the borders of the Cold War, where West and East met face to face, interactions between policies and practices of state agencies and citizens were most intense. Borders were the production facilities for the mindsets, self, and other perceptions and social structures of the Cold War-none more than the inter-German border, which carved "East" and "West" out of a previously unified society.

This article shows that the western campaign to isolate the GDR made issues related to its recognition a top priority for state agencies in east and west alike.

\footnotetext{
${ }^{10}$ Sheffer, "Burned Bridge," 560-70. I thank Edith for first pointing out to me the similarity between the two stories as I was working on an early version of this article.
} 
Considerations of recognition trumped potential benefits of coordination and undermined cross-border contacts. Close supervision by central state agencies devalued local and regional border-crossing communities, contributing to the emergence of boundaries dividing a previously unified society.

The regional negotiation attempt analyzed in this article demonstrates that in the second half of the 1950s regional communities sprawling across the eastwest divide were still vital. The case presented in Sheffer's dissertation further supports this finding. In both cases, local administrators easily found ways to contact each other and engaged one another willingly. Popular opinion in their districts favored border-crossing meetings and cooperation. In both cases, too, the negotiations failed to achieve progress and resolve any issues of substance because of the limitations imposed by superior state agencies. These similar lines of development highlight the limits of agency of frontier residents in the process of division. State agencies dictated very rigid rules regarding border-crossing contacts. Even when frontier administrators openly pushed against these rules and enjoyed popular support, state agencies remained immovable. Demonstrating this, the article argues that crucial elements in the historical transformation of German division have not been accounted for as of yet. It shows, further, that West German policies, specifically, were more causal in bringing about division than realized in previous studies.

To explain how inter-German contacts came to be so severely proscribed during the 1950s as to undermine cross-border communities in the Eichsfeld and elsewhere, I turn first to a short history of the western claim to exclusive representation of the German people.

\section{Nonrecognition and its Discontents}

The Federal Republic of Germany's (FRG) claim to exclusive representation of the German nation, embodied in the diplomatic battle against recognition of the GDR, undermined cross-border coordination and contributed to the division of Germany. Throughout most of the 1950s and 1960s, western and eastern state agencies pursued goals dictated by the battle over recognition and legitimacy of the East German state. The best-known front in this war was international diplomacy, but along the inter-German border daily battles were waged on a less glamorous frontline of the same war.

\section{The Origins of the Claim to Exclusive Representation}

Allied policies had pushed the eastern and western parts of Germany apart since 1945, yet the Allies never officially abandoned their commitment to the future reunification of Germany as written into the Potsdam agreement. The western Allies' rejection of the Stalin Note dated March 10, 1952, indicated that 
unification did not lie around the corner, however. ${ }^{11}$ Under Konrad Adenauer's leadership, the new West German state made securing greater independence and western integration its central goals, while also professing commitment to achieving German reunification. The early 1950s demonstrated how difficult it was to form a coherent policy that promoted all these goals simultaneously that would be publicly acceptable, diplomatically viable, and politically realistic. ${ }^{12}$ Within the first half of the decade, the FRG reestablished an army and an armament industry, became a founding member of the (west) European Coal and Steel Union, and joined NATO. Partly in return, it gained growing formal independence from the western Allies, which allowed the West German government to establish a foreign ministry and diplomatic relations. The western Allies' occupation of West Germany formally ended with a treaty they signed with the FRG in May 1955. Throughout this period, officials of the federal government repeatedly reiterated its commitment to German reunification. More than that, the FRG was committed to a denial of Germany's division. Adenauer and other government officials time and again stated the claim to exclusive representation of the German people, enshrined in the republic's Basic Law (Grundgesetz). According to this principle, "Until Germany was restored as a unified state, the government of the Federal Republic — which alone had been elected in a free democratic manner-would act as the sole legitimate representative of the German people." 13 In practical terms, this meant that the FRG refused to deal with the East German state or acknowledge that the territory beyond its eastern border was anything other than Soviet-occupied territory.

The western Allies supported West Germany's claim to exclusive representation of the German nation. After the establishment of the GDR in fall 1949, they devised a strategy aimed at deterring any country from recognizing the new socialist state and establishing relations with it. Bonn followed suit and made the international isolation of the East German regime a cornerstone of its

\footnotetext{
${ }^{11}$ See Rolf Steininger, Eine Vertane Chance. Die Stalin-Note vom 10. März 1952 und die Wiedervereinigung (Berlin: J. H. W. Dietz Nachf., 1985), 9, for a summary of the document's content. For many years, scholars and politicians in Germany and elsewhere debated the sincerity of this suggestion and the reaction of the Allies and the German government. See Gerhard Wettig, "Stalin and German Reunification: Archival Evidence on Soviet Foreign Policy in Spring 1952," The Historical Journal 37 (1994): 411-419. See also Wilfrid Loth, Die Sovjetunion und die deutsche Frage (Göttingen: Vandenhoeck \& Ruprecht, 2007), 12-26.

${ }^{12}$ Werner Kilian, Die Hallstein-Doktrin. Der diplomatische Krieg zwischen der BRD und der DDR 1955-1973 (Berlin: Duncker \& Humblot, 2001), 14-15; Ludwig Auerbach, "Das ganze Deutschland soll es sein," in Adenauer und die Folgen, ed. H. J. Netzer (Munich: Beck, 1965), 92-105.

${ }^{13}$ William Glenn Gray, Germany's Cold War: The Global Campaign to Isolate East Germany, 1949-1969 (Chapel Hill, NC: University of North Carolina Press, 2003), 11-12. See also Kilian, Die Hallstein-Doktrin, 18-19.
} 
foreign policy. The federal government announced that it would sever relations with any state that would recognize "the so-called GDR."14

The Soviet Union put this strategy to the test in summer and fall 1955, when Khrushchev invited Adenauer to Moscow. The prospect of diplomatic relations between the FRG and the Soviet Union raised questions regarding the West German policy on relations with the GDR, but Adenauer's government reaffirmed its standing on this point. Preparing for the visit during summer 1955, West German policy makers decided to demand progress on German reunification and to avoid any formal recognition of the GDR. They agreed that if the Soviet Union's leader wished to discuss diplomatic relations with the FRG, the Germans would agree to establish committees to discuss the issue but not more. During the visit in September, the Soviets refused to discuss reunification, insisting that Adenauer should broach this question with the GDR leadership if he wished. As the West German delegation was setting to depart in protest, the Soviets made an offer: they would release the remaining ten thousand German prisoners of war held in the U.S.S.R. in return for the establishment of diplomatic relations with the FRG. The offer was politically too valuable for Adenauer to pass up: returning the prisoners to their homes and families was bound to boost his popularity. To the amazement of his senior advisers, Adenauer reversed on their decisions in the preparatory discussions and accepted the offer. Before returning to Germany, Adenauer submitted a letter to the Soviets stating the FRG's claim to exclusive representation of the German people and his government's refusal to accept the postwar borders. This was just a face-saving gesture, not a negotiating move-Adenauer did not expect the Soviets to consent. ${ }^{15}$

Opening an embassy in a city that already hosted a GDR embassy, Adenauer put the practice, if not the whole theory, of exclusive representation at risk. How would the FRG be able to dissuade other countries from establishing relations with the GDR? On the plane back, the top Foreign Office officials began to assess their options given the new situation. The basic claim of the new policy they formulated was that nothing had changed. Moscow presented a unique problem and the FRG found a unique solution to it. The Soviet Union held the POWs and was one of the war-time allies, all of whom had committed to German unity, so Bonn made an exception. In no other state in the world would West Germany accept the existence of two German embassies. In his press conference upon returning to Bonn, as well as in a Bundestag speech summarizing the visit, Adenauer warned that Bonn would consider establishing

\footnotetext{
${ }^{14}$ To avoid using the title "German Democratic Republic," West German speakers usually referred to it as "the Soviet Zone" (Sovietische Besatzungszone, or SBZ) or "the so-called GDR" (die sogenannte DDR). Some preferred "central Germany" (Mitteldeutschland), alluding also to the Germanness of the territories annexed by Poland and the Soviet Union that belonged to Germany before World War II.

${ }^{15}$ Gray, Germany's Cold War, 30-37; Kilian, Die Hallstein-Doktrin, 13-18; Rüdiger Marco Booz, "Hallsteinzeit.” Deutsche Aussenpolitik 1955-1972 (Bonn: Bouvier Verlag, 1995), 17-20.
} 
relations with the GDR an "unfriendly act." It took a few more months before the details were rounded into an official policy that was presented in a conference to foreign ambassadors in Bonn. The official letter was signed by Foreign Office State Secretary Walter Hallstein. All the elements in the diplomatic formula had been used before, but this was the first repackaging of all these elements as an official West German policy, which was thereafter known as "the Hallstein Doctrine." 16 Despite internal and external criticism and a less than impressive record, this policy held firm thereafter until the establishment of the CDU/ CSU and SPD "big coalition" government in December 1966. ${ }^{17}$

\section{Exclusive Representation and the Inter-German Border}

Such a policy, which denied the existence of a neighboring state holding much power over the lives of millions of Germans, gave rise to many contradictions. Eastern state agencies were present and their practices visible, and western state agencies' insistence on ignoring them forced both sides into corners. In no area were such problems clearer or more significant to the lives of German citizens than in West German border policy and its implementation. Policies related to exclusive representation and the ensuing battles over recognition of the GDR hampered frontier residents' ability to overcome some of the negative effects of German division. Convinced that they were paying the price for Bonn's unrealistic positions, western frontier residents criticized and occasionally subverted their state's policies. ${ }^{18}$

Even before the Hallstein Doctrine was formulated, the West German claim to exclusive representation of the German people had turned the recognition of the GDR into the crux of the diplomatic battle between the two German states. The western Allies and the West Germans were dependent on cooperation with the Soviets for many things (such as ground travel from West Germany to West Berlin). In May 1952, the East Germans and the Soviets increased this dependency and used it in an attempt to force the west to recognize the GDR at least de facto. On the morning of May 27, 1952, the GDR announced a

\footnotetext{
${ }^{16}$ Gray, Germany's Cold War, 37-40; Kilian, Die Hallstein-Doktrin, 18-23; Booz, "Hallsteinzeit," 17-19.

${ }^{17}$ Gray, Germany's Cold War, 193-198; Kilian, Die Hallstein-Doktrin, 339-340; Booz, "Hallsteinzeit," 97-104. As a unique phenomenon in international relations, the Hallstein Doctrine was analyzed and studied by many. The three books quoted above, published in the space of eight years, summarize well its inception, different practices, difficulties, effects, and eventual demise. See also Martin H. Geyer, "Der Kampf um nationale Representation. Deutsch-deutsche Sportbeziehungen und die 'Hallstein Doktrin," Vierteljahrshefte für Zeitgschichte 44 (1996): 55-86.

${ }^{18}$ Edith Sheffer recounts the story of border-crossing relations between Sonneberg and Neustadt bei Coburg in the 1950s. The district administrator of the eastern district was fired in 1958 for agreeing to discuss issues of content with his western colleagues, and the mayor of Neustadt decided to disregard pressures from Bonn and continue with public official meetings with his colleagues from the east, drawing much media attention in 1959-60. Sheffer, "Burned Bridge," 565-68.
} 
dramatic change in border policy, declaring its border with West Germany officially impenetrable. ${ }^{19}$ This new policy included the abolition of all local and regional arrangements allowing easy border crossing with renewable permits for people who worked, studied, or owned property across the border from where they lived. ${ }^{20}$ At the same time, many checkpoints along the border were closed, and crossing the border became difficult and time-consuming. The border was to be fortified by erecting a fence, clearing a ten-meter strip east of the fence, and declaring a five-hundred-meter strip and a five-kilometer strip as restricted areas with ascending levels of security. During the following weeks, East German forces deported thousands of "untrustworthy people" from the restricted areas into the GDR hinterland and mobilized or coerced thousands of others to build fences and clear forests along the border. ${ }^{21}$ The government instructed district and community councils to notify the population that crossing the control strip along the border was absolutely prohibited for all. The order further stated that "the border police received instructions [that] in cases of nonobservance of the orders of border patrols, weapons should be used." 22 The visibility and impact of GDR state agencies along the border had increased manifold overnight, and frontier residents were forced to come to terms with them.

\footnotetext{
${ }^{19}$ For preparations to the announcement of the new border regime in the GDR, beginning in early May, see BAMA, DVH 27 Pt7493. For the purposes of the argument in this paper, see especially 50, 63-67. See also Besondere Massnahmen an der D-Linie, Weimar, May 3, 1952, in BAB, DO 1, 20.0/ 642, for measures to tighten and even seal parts of the border as early as May 3. See a good step-by-step document analysis of the weeks leading to the declaration of the new border regime in Inge Bennewitz and Rainer Potratz, Zwangsaussiedlungen an der innerdeutsche Grenze. Analysen und Dokumente (Berlin: Links, 1997), 26-33. For the broader context of this policy change in the GDR, see Ross, Constructing Socialism, especially part 2 beginning on 51. For the Soviets' instructions to the East Germans as early as April 1952, see Lapp, Gefechtsdienst im Frieden, 19-20.

${ }^{20}$ These arrangements operated for more than five years at that point and are generally referred to as "little border traffic" (kleine Grenzverkehr). All community councils received a detailed copy of the new order stating explicitly that "Die Bestimmungen über den kleinen Grenzverkehr sind mit Wirkung vom 26.5.52 aufgehoben" (the regulations governing the little border traffic are abolished as of May 26, 1952). See, for example, KrAEich, Kirchgandern B14. This element was an important part of the new border regime, and the central command of the border police worked on different versions of its phrasings in advance. See BAMA, DVH 27, Pt 7493, 50.

${ }^{21}$ Edith Sheffer, "The Foundations of the Wall: Building a 'Special Regime' in the Borderland," unpublished paper presented at the German Studies Association's Annual Conference, 2006, describes in detail the effects of this new policy on the frontier population and references the major works on this issue. See also Rainer Potratz, "Zwangsaussiedlungen aus dem Grenzgebiet der DDR zur Bundesrepublik Deutschland im Mai/Juni 1952," in Grenzland. Beiträge zur Geschichte der deutschdeutschen Grenze, ed. Bernd Weisbrod (Hannover: Hahnsche Buchhandlung, 1993), 57-69; and the very useful collection of documents pertaining to the deportation of frontier residents in the GDR in Bennewitz and Potratz, Zwangsaussiedlungen. Different state agencies in the GDR wrote daily reports on the implementation of the new border regime and the atmosphere along the border. See, for example, KrAEich, EA HIG 192; ThHStAW, Land Thür. MdI Nr. 3039, 4-9; BAB DE 1, 6084, 178-179, 185-186.

${ }^{22}$ KrAEich, Kirchgandern B14. In practice the border police department at that time was undermanned, under equipped, and not in a position to impose such regulation in a strict manner.
} 
At the same time, the Soviets notified the western Allies of a change in procedures for border crossing. German citizens wishing to travel into or pass through the GDR were required from then on to have special permits issued by the East German People's Police. The Soviets proceeded to remove passengers who did not possess such permits from trains crossing the border. ${ }^{23}$ Their unwillingness to coordinate anything with a police force of a state they did not recognize put the western Allies and the FRG in the difficult position of being unable to ensure travel to Berlin for West German citizens. The new GDR border regime in May 1952 worked in similar ways. Practices that were previously regulated between the Allies or on the local level only, such as the operation of bordercrossing bus and train lines, had to be renegotiated with East German state agencies. With the new border policy, the GDR created leverage for recognition. On a daily basis, it produced thousands of routine demonstrations for West Germans that it existed and had power over their lives, each of them an incentive for these citizens of the FRG to support cross-border cooperation. The timing was no coincidence. As Corey Ross has shown, 1952 marked a turning point in the East German state-building project. Proclaiming its authority more boldly, the GDR attempted also to force the west to accept it. ${ }^{24}$ This strategic move raised the stakes of border policy on both sides, making the borderlands a major battlefield in the German Cold War over the recognition of the GDR. Cross-border contacts thus acquired explosive potential and state agencies on both sides began to supervise frontier officials' contacts with colleagues across the border more closely.

Throughout the 1950s, frontier residents and local politicians, such as mayors and district administrators, tried to find arrangements and mechanisms to enable meeting the daily needs of frontier society in an environment greatly troubled by the emerging political division. Administrators and politicians in frontier communities and districts were forced to engage the contradiction between their superiors' priorities, framed by diplomatic "all-German" strategies, and the demands and needs of their communities and regions. Many local administrators tried to make cross-border coordination work, knowing from experience that this was an effective way to manage their resources and promote local interests. Frontier administrators were very interesting players in this history, on the boundary between state and non-state parts of society, often embodying the effort to differentiate the two. ${ }^{25}$ Some frontier administrators were defiant of authority;

\footnotetext{
${ }^{23}$ McCloy to State Secretary, May 28, 1952, and July 2, 1952, in NARA-CIV RG 59 1311/250/ $59 / 17 / 7 / 11 / 1$.

${ }^{24}$ Ross, Constructing Socialism, 51. I argue that the transformation in GDR policy Ross discusses was expressed in the clearest manner in the area of border policy.

${ }^{25}$ See Timothy Mitchell, "The Limits of the State: Beyond Statist Approaches and Their Critics," American Political Science Review 85 (1991): 77-96; and Gil Eyal, The Disenchantment of the Orient: Expertise in Arab Affairs and the Israeli State (Stanford, CA: Stanford University Press, 2006), 7-8, 12,
} 
others toed the line more carefully. But regardless of the approach each took, their initiatives for cross-border cooperation all failed. The battle over recognition had pulled many cross-border networks and communities apart at the seams by diminishing their relevance in daily life.

\section{Exclusive Representation and the Demise of Border-Crossing Cooperation}

Policies related to exclusive representation created very rigid battle fronts between the two German states, too rigid to allow coordination between officials on both sides of the border to materialize in stable, productive relations. State agencies stymied local efforts at cross-border cooperation, giving rise to repeated enactments and experiences of division. Instead of promoting mutual interests and solving practical problems, frontier administrators were forced into disputes over the nature of the cooperation, technical or political, local or inter-state.

\section{How Regional Identification Fell Victim to the Battle over Recognition ${ }^{26}$}

In the Eichsfeld region, border-crossing cooperation had been the most common way to address the challenges of local and regional administration and economy before 1945. State and province borders had divided the Eichsfeld since the early nineteenth century. These borders did not stand in the way of cooperation on a local or regional basis. There was no physical obstacle in place and farmers routinely cooperated to return stray cows, combat fires, or coordinate hunting to minimize damages to agriculture. For these purposes, there was no difference between cooperation among neighbors across the border and those on the same side. The management and regulation of water resources presented the best example of large-scale regional cooperation. Due to the topography of the Eichsfeld, mountainous in the east and flat in the west, water in many smaller and a few larger streams generally flowed across the border from east to west. Regulating and clearing riverbeds was routinely carried out in coordination between neighboring communities along streams, regardless of any borders.

108-119. For a development of the theory elaborated by these two authors regarding the connection of the boundaries between state and society with the borders between states, and for an application of this conceptualization to the history of German division, see Sagi Schaefer, "Ironing the Curtain: Border and Boundary Formation in Cold War Rural Germany" (Ph.D. diss., Columbia University, 2011), 34-38.

${ }^{26}$ Following Rogers Brubaker and Frederick Cooper, I chose not to employ the term "identity" in this article. They suggest the use of "identification" instead because "As a processual, active term derived from a verb [it] lacks the reifying connotations of 'identity.' It invites us to specify the agents that do the identifying. And it does not presuppose that such identifying . . will necessarily result in internal sameness . . . Identification . . . is intrinsic to social life; 'identity' in the strong sense is not." Rogers Brubaker and Frederick Cooper, "Beyond 'Identity," Theory and Society 29 (2000): 1-47; quote on 14. 


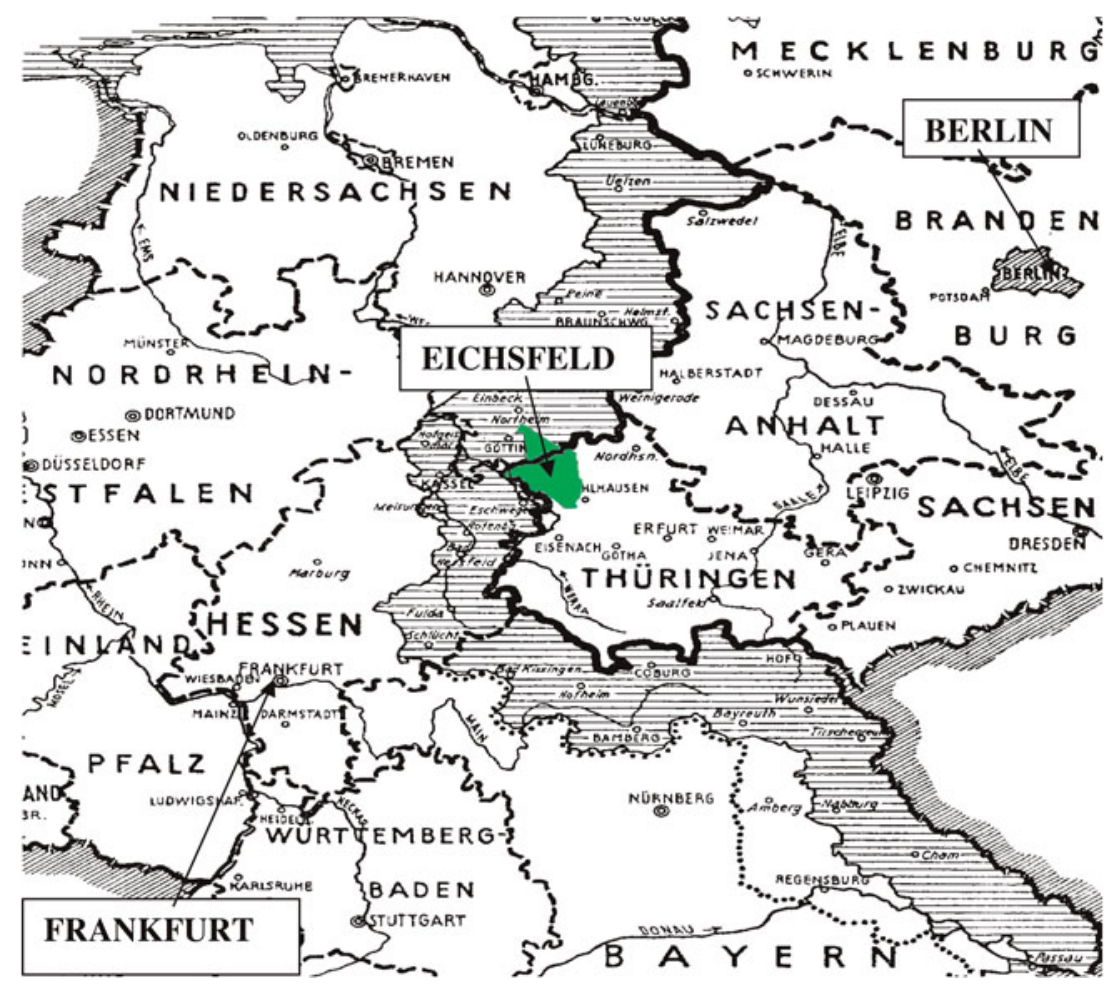

Map 1: Map of the inter-German border marking the location of the Eichsfeld region. Source: Copied and edited from Bundesministerium für Gesamtdeutsche Fragen, ed., Im Schatten der Zonengrenze (Bonn: Bundesministerium für Gesamtdeutsche Fragen, 1956), 5.

When the town of Duderstadt (west of the border) needed to increase its water supply in the interwar years, it turned to the neighboring community of Brehme (east). An agreement was struck whereby Duderstadt purchased a patch of land in Brehme where a deep well and necessary canals were dug to lead the water to the town. No one thought much of the provincial border between the two communities at the time. ${ }^{27}$

Cross-border cooperation continued to play an important role in the postwar years until 1952 in the Eichsfeld, even as old administrative borders traversing the region turned into demarcation lines between occupation zones and statebuilding projects (see Map 1). The ease of cooperation in the Eichsfeld helped

\footnotetext{
${ }^{27}$ The project was completed in 1933. This arrangement became a problem and was discussed and negotiated repeatedly on many levels from the early 1950s. See, for example, Verbindungen nach Westdeutschland, die die Staatsgrenze berühren, Worbis, June 11, 1963, in KrAEich, EA WBS Nr. 7241.
} 
frontier residents overcome some of the problems created by emerging processes of division. The arrangement reached among the western town of Duderstadt, the farmers of the eastern village of Ecklingerode, and the eastern district of Worbis provide a good example. Duderstadt agreed not to collect land taxes from farmers from Ecklingerode whose fields were in its domain. In return, the farmers agreed to pay these sums to the district of Worbis, which would use them to pay foresters for keeping Duderstadt's town forest (east of the border) in order and supplying Duderstadt with wood. In this way, the individuals and state agencies involved circumvented the difficulties posed by the conflicting regulations pertaining to converting eastern and western currencies on both sides of the border. ${ }^{28}$ The economy of these borderlands depended on many cross-border interactions and arrangements of this kind to keep afloat in the years prior to 1952. But even in the Eichsfeld, cross-border cooperation became increasingly difficult after 1952, with state agencies on both sides gradually restricting contact options, especially between officials.

The attempts to reopen the border checkpoint in the Eichsfeld demonstrate how state agencies' priorities prevented solutions to problems along the border. The most important issue on the agenda for frontier administrators in the Eichsfeld after 1952 was the quest to reopen the border checkpoint between Gerblingerode and Teistungen. This checkpoint on the road from Hanover to Erfurt, connecting Duderstadt with the eastern Eichsfeld, was the only one in the region. It was closed as part of the GDR's reform of border regulations in May 1952, turning the road to Duderstadt into a dead-end road and thus severely damaging the economy of the region. Appeals by the western Allies to the Soviets to reopen the checkpoint were met with Soviet refusals to discuss matters falling under the jurisdiction of the GDR. The Minister President of the county of Hildesheim then notified the district administrator in Duderstadt that the government authorized "local German administrations to discuss technical issues for the reopening of border checkpoints" with their East German counterparts (emphases in the original). ${ }^{29}$ With this limited authorization, the district administrator in Duderstadt tried to engage his colleague in Worbis in a discussion of the chances to reopen the checkpoint. The chief administrator in Worbis agreed in principle to discuss it but repeatedly invoked his view that border controls were state matters. He explained that there were issues of currency exchange,

\footnotetext{
${ }^{28}$ Correspondence on this issue, beginning in March 1951, can be found in ThHStAW, Land Thür., Ministerium d. Finanzen Nr. 1397. See especially documents from March 28, 1951 (Kreisrat Worbis to Th. MdI), April 30, 1951 (internal memo Th. Landesfinanzdirektion). See also many other examples detailed in the document from May 5, 1951 (inspection report of Th. MdF detailing the different local and regional solutions).

${ }^{29}$ Oberkreisdirektor Dud to Regierungspräsident Hildesheim, Dec. 4, 1953, and Regierungspräsident Hildesheim to Oberkreisdirektor Dud, Jan. 23, 1954. Both in KrAGö, LK DUD Nr. 61. The quote is from the second letter.
} 
permits, and more involved in opening a checkpoint that local administrators could not regulate themselves. Throughout 1954, the two exchanged letters on the subject but the eastern administrator showed no intention to move. ${ }^{30}$

\section{Culture is Safe: How West Germany Agreed to Border-Crossing Contacts}

The cementing of the battle over exclusive representation after 1952 led West German state agencies to restrict all cross-border contacts between officials, fearing they might be presented as proof of recognition. With increasing problems in frontier economy and society caused by the political division and with the proven potential of cross-border cooperation for solving such problems, frontier administrators saw these restrictions as hindering their ability to perform their responsibilities effectively. The district administrator of the rural district of Duderstadt, the western part of the Eichsfeld, Matthias Gleitze, understood his superiors' reservations about such meetings, but saw cooperation with colleagues from the east as the only way to promote some key interests of his district's population. Gleitze was a native of the Eichsfeld and an expert in Eichsfeld agriculture. He was active in the Center Party and spoke publicly against the NSDAP, an act that cost him the position he held in the civil service in 1933 but allowed him to regain one in 1947. He was elected head of the district administration (Landkreisdirektor) in 1948, a position he held until his retirement in 1967. ${ }^{31}$

In summer 1953, Gleitze was personally invited to meet with his counterpart in Worbis. He requested permission from his superior in the county of Hildesheim to accept the invitation. He explained that he knew the GDR side was going to try and score propaganda points if he led an official delegation across the border. He then emphasized that despite the political risk, such a meeting would be worthwhile because there were many burning local issues that could be solved through cross-border coordination in an area such as the Eichsfeld, with six hundred years of close relations. Among the issues he mentioned were the reopening of the border checkpoint discussed above, but also permits to cultivate the Duderstadt town forest which lay across the border, prompt return of straying

\footnotetext{
${ }^{30}$ Further correspondence throughout 1954 is in the same file, including a report from a surprise visit of one council member from Duderstadt in Worbis. Some examples include Oberkreisdirektor Dud to Vorsitz. d. Kreistags WBS, Feb. 23, 1954; Vorsitz. d. Kreistags WBS to Oberkreisdirektor Dud, March 4, 1954; Aktenvermerk by Garre on visit in Worbis, Aug. 18, 1954. All in KrAGö, LK DUD Nr. 61.

${ }^{31}$ Gleitze was born in 1902 in Seeburg, about five miles northwest of Duderstadt as the crow flies. After retiring he served in the district council and in the council of the city of Duderstadt. He died in 1989, just three weeks before the border opened. For details about Gleitze's life and career, see http:// de.academic.ru/dic.nsf/dewiki/930693 (last accessed June 27, 2010). Gleitze earned a Ph.D. in national economy at the University of Rostock in 1927, after having written a dissertation about the development of plot sizes in the district of Duderstadt and its consequences. On the front cover of his dissertation, below his name and title, Gleitze added "from Seeburg in the Eichsfeld." See M. Gleitze, "Die Verteilung und Bedeutung der Betriebsgrössen in der Landwirtschaft des Kreises Duderstadt" (Ph.D. diss., Rostock University, 1926).
} 
livestock, and permission for conversations between relatives across the border fence. ${ }^{32}$ His passionate and calculated attempt, and his promises to avoid any overtures from eastern officials to discuss political matters, did not help. His superiors gave this initiative a bureaucratic burial by stalling. At the council meeting in Duderstadt, Gleitze explained his rejection of the invitation in these words:

To be on the safest side, I asked the [county] government whether it would be possible [to go to Worbis]. They needed to consult the [Lower Saxon] Minister of the Interior. It is quite clear that if I or a committee would travel to Worbis, Leipzig radio broadcasts would say that there is a delegation in Worbis today. That might be taken the wrong way here. Then we would have a case of lower authorities going against higher authorities. ${ }^{33}$

Gleitze thought he needed explicit permission, and he read administrative language well enough to understand that the county officials' stalling beyond the date of the expected visit was their way of rejecting his request.

The breakthrough in the impasse about border-crossing meetings in the Eichsfeld began in the village of Holungen about 3.5 miles southeast of the inter-German border (see Map 2). Holungen was the birth and burial place of Hermann Iseke (1856-1907), regarded as the Eichsfeld's "homeland poet" (Heimatdichter). In December 1954, a local committee was formed in the village to organize an Eichsfeld celebration for the upcoming centenary of the poet's birth. The village council wrote to the district of Worbis requesting approval and support for the project. ${ }^{34}$ Party functionaries in the district asked for more details about Iseke, probably to ascertain that his history and politics did not conceal any unwelcome surprises, and they were reassured by the response. The organizing committee was instructed to join the German Socialist Unity Party (SED)-affiliated "League of Culture" (Kulturbund). ${ }^{35}$

After receiving a green light, the village cultural committee began preparing a regional event, celebrating Eichsfeld traditions. The SED activists in the region tried to add political overtones, events, and symbols to the celebration to highlight the GDR's success and strength. They also sought to tone down the religious emphasis of the planned event. One of the major conflicts between the local

\footnotetext{
${ }^{32}$ Oberkreisdirektor Duderstadt to Regierungspräsident Hildesheim, June 1, 1953, in KrAGö, LK DUD Nr. 61.

${ }^{33}$ Undated Kreistag protocol, KrArGö, LK DUD Nr. 61. This western policy prohibiting bordercrossing meetings between officials was not unique to the Eichsfeld. Edith Sheffer writes that Bavarian officials forced city councillors in Neustadt to cancel meetings they had already agreed to participate in at the same time. See Sheffer, "Burned Bridge," 562-3.

${ }^{34}$ Rat d. Gemeinde Holungen to Vorsitz. d. Rates d. Kreises Worbis Dec. 20, 1954. KrAEich, Holungen B58.

${ }^{35}$ The SED was the East German ruling party. For the letter with the reassuring details about Iseke's background, see Rat d. Gemeinde Holungen to Vorsitz. d. Rates d. Kreises Worbis, Feb. 21, 1955. KrAEich, Holungen B58. See also Jan Palmowski, Inventing a Socialist Nation: Heimat and the Politics of Everyday Life in the GDR, 1945-1990 (Cambridge: Cambridge University Press, 2009), 229-31.
} 


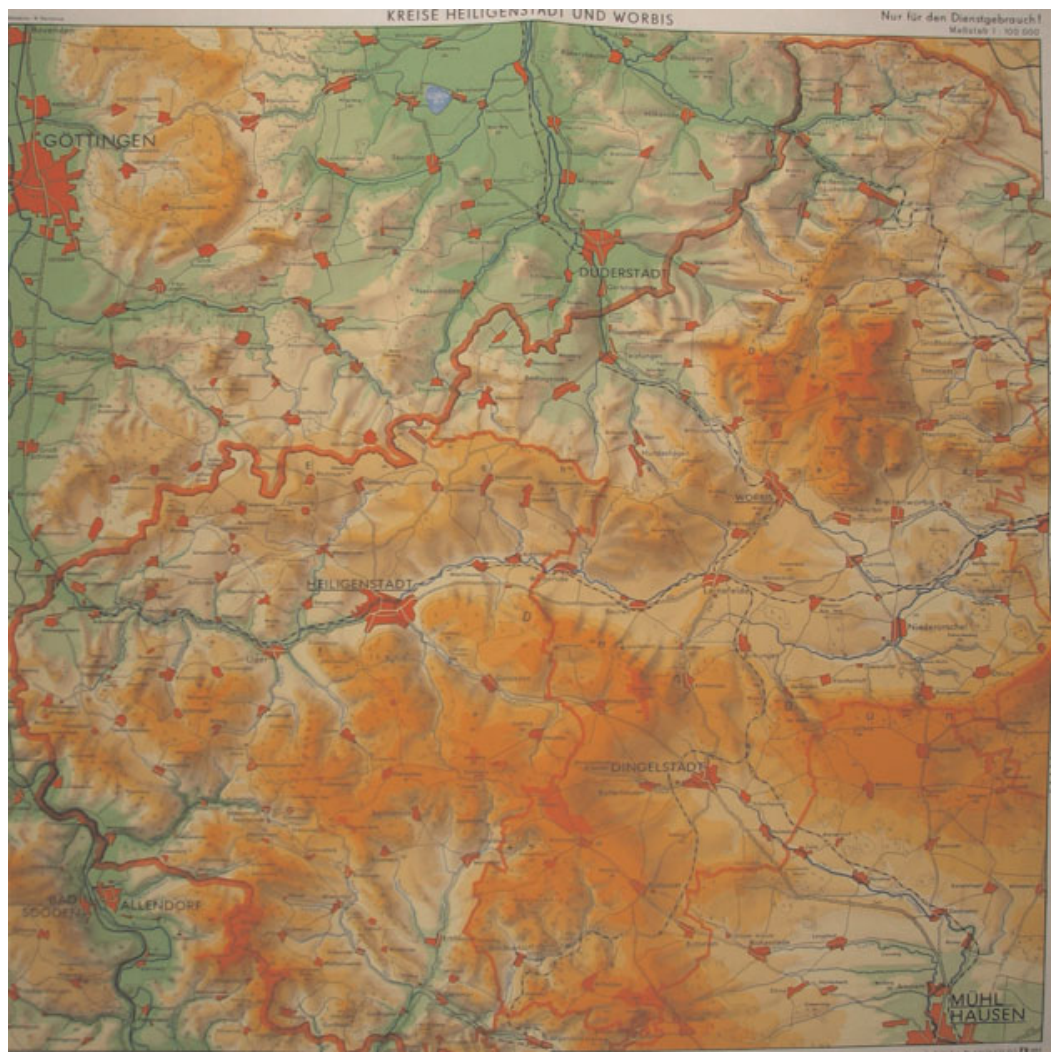

Map 2: Map of the Eichsfeld from 1984 showing GDR district boundaries. Source: Eichsfeld District Archive. ${ }^{36}$

committee and the district party chiefs was the giant electrically lit cross that the committee planned to erect on top of the hill facing west, to be seen across the border day and night, symbolizing the unity of the Eichsfeld. Eventually, the event as presented in invitations sent to western Eichsfeld communities and the district authority seemed benign enough to win the approval of West German state agencies. It was not a political event but a celebration of shared heritage, and Gleitze was able to win his superiors over to allowing the participation of western Eichsfeld residents, himself included. ${ }^{37}$

\footnotetext{
${ }^{36}$ I thank Frau Regina Huschenbeth, director of the Eichsfeld district archive, for allowing me to use this map.

${ }^{37}$ See one example of the invitations to West German Eichsfeld communities and to the western district of Duderstadt, titled "Eichsfeld Homeland Gathering, a Contribution to Peace and Unity" (Eichsfelder Heimattreffen, ein Beitrag für Frieden und Einheit), in KrAGö, LK DUD Nr. 61.
} 
The eventual regional festival in Holungen on July 7-8, 1956, was a true Heimatfest. Major highlights of the first evening included the unveiling of the Iseke memorial, a torchlight procession, and the lighting of the cross atop the westward-looking hilltop of the Sonnenstein. A bonfire was lit near the cross and was "answered" by two bonfires from the hills of the western Eichsfeld. The second day began with a public mass, and its climax was a pageant with Eichsfelder from across the region in traditional costumes. The major events attracted more than 10,000 participants from the region, including hundreds from the western Eichsfeld. Western participants were requested to apply for permits in advance and were forced to travel for hours through a remote border checkpoint, but many apparently crossed illegally and joined the event unregistered. The eventual character of the event was determined primarily by the massive participation of Eichsfelder and emphasized the shared Catholic traditions of the region. ${ }^{38}$ Regional identification and the will to uphold the crossborder community were still strong among Eichsfelder in 1956. Voting with their legs and with the contents chosen for their Heimatfest, residents clearly expressed their devotion to the idea of a unified Eichsfeld. ${ }^{39}$

\section{Cultural Contacts and the Politics of Recognition}

Gleitze, the highest-ranking western official present, reported no politically offensive transgressions upon returning home from the Iseke festival. Yet, for the council members from the host district of Worbis, inter-German politics had nevertheless been part of the event. There are indications that around that time, party circles in the GDR had identified regional culture in the Eichsfeld as a potential tool in their quest to win western recognition. The secretary of the district council sent four of his deputies to engage with the visitors and especially with the politicians coming from the west. Gleitze was not averse to

\footnotetext{
${ }^{38}$ For applications to participate from the western Eichsfeld, see Oberkreisdirektor Kreis Duderstadt to Vorsitz. d. Rates d. Kreises Worbis, June 11, 1956, in KrAGö LK DUD Nr. 61. The same file also includes the program of the event and some newspaper reports on it. See Eichsfelder Heimatbote, July 21, 1956, "Das ganze Eichsfeld - ungeteilt" as cut and saved in the district archive in the western part of the Eichsfeld, KrAGö LK DUD Nr. 61. For more details on the contents of the celebration, the number of participants, and the locals' perspectives on its impact, see Palmowski, Inventing a Socialist Nation, 229-234. It is hard to determine exactly how many participants came from the western part of the Eichsfeld region. Palmowski relies on GDR newspaper reports and on locals' memories to say that there were as many as eight hundred participants from the west (230), but permits were issued for only 250, who boarded buses and traveled the long way through Wartha. See Stadt Duderstadt, Die Grenze im Eichsfeld (Göttingen: Verlag Göttinger Tageblatt, 1991), 16. The additional participants must have arrived via shorter, unofficial, and illegal routes.

${ }^{39}$ According to Edith Sheffer, this was the case in Sonneberg and Neustadt that time as well. Officials and residents of the two border towns were overwhelmingly in favor of border-crossing meetings and ceremonies; they voted for them when given the chance, held them in spite of repeated reprimands and prohibitions, and still remember them fondly today. Sheffer, "Burned Bridge," 564-68.
} 
their courting. Having finally acquired official approval for a formal visit in the eastern part of the Eichsfeld region, he was quite happy to reestablish working relations with his colleagues there. In his reports, therefore, he emphasized the harmless nature of these conversations, which touched only on topics such as returning stray animals, regulation of waterways, and warnings in cases of fire along the border. ${ }^{40}$

The SED in the Eichsfeld used this event to plant the seeds for a concerted effort to turn Eichsfeld cultural unity and tradition into an instrument of "allGerman work" (gesamtdeutsche Arbeit). ${ }^{41}$ In fact, it had begun to move in this direction even before the Holungen event. During fall 1955, plans were made for a concert of the Heiligenstadt (in the eastern Eichsfeld) choir to perform in Duderstadt (in the west). At the same time, the district of Worbis encouraged the mayors of the three towns of the eastern part of the Eichsfeld region (Dingelstädt, Worbis, and Heiligenstadt) to initiate a meeting with the mayor of Duderstadt, the only town in the western part. ${ }^{42}$ The practice of initiating conversations with private visitors from the west and inviting them to public events, a cornerstone of all-German work in the GDR, was also restructured to instrumentalize regional culture. In previous years, visitors were invited to private conversations with the mayor or to tour factories and schools and hear about the progress in East Germany. In April 1956, the town of Heiligenstadt invited visitors from the west to a lecture about "poetry in the Eichsfeld dialect" followed by a slide show titled "our Eichsfeld." 43 By the mid-1950s, SED circles came to view regional traditions, networks, and identifications as potential tools in their attempts to persuade West German citizens that the GDR was a stable, peace loving, and friendly neighbor state.

From 1955 to 1958, cross-border connections between district administrations in the Eichsfeld supplied an arena for repeated enactments of the drama of the inter-German battles over exclusive representation. The region's common religion, traditions, and concerns served as opportunities for meetings and correspondences between administrators. Both sides had many issues they wanted to coordinate with their colleagues across the border. For residents of these areas,

\footnotetext{
${ }^{40}$ In his first report, he emphasized that in the conversations with his colleagues from the neighboring GDR district, they avoided discussions of any political questions ("unter Vermeidung aller politischen Fragen") and concentrated on this kind of local issues. See Oberkreisdirektor Duderstadt, Aktenvermerk, July 12, 1956, in KrAGö LK DUD Nr. 61.

${ }^{41}$ Under this title, state and party officials, organizations, and citizens of the GDR were encouraged to contact West Germans and persuade them of the peaceful, just, and moral way of the East German state so as to win them over for the eastern positions in the Cold War. For examples of "all-German work" in other frontier areas, see Sheffer, "Burned Bridge," 342-45.

${ }^{42}$ See Rat d. Kreises Worbis an den Rat d. Stadt Heiligenstadt, Nov. 24, 1955, in StArHIG Rep II, IA Nr. 560 .

${ }^{43}$ See the invitation to the event in StArHIG Rep II, IA Nr. 560.
} 
which had turned into frontier lands, the inter-German border was not simply a diplomatic, geopolitical issue. It had changed many aspects of their daily lives and significantly hampered their economy. The most insidious was perhaps the change in the region's place on the transportation map. From a central location, lying between highways and railways, the Eichsfeld had turned into a peripheral end-of-the-road station after railways and roads were severed by the border. Bus lines were canceled and the national railway company reduced-and in the west canceled - service, even to the district towns. Transportation costs for private citizens and businesses rose significantly, and people had to ride bikes or walk miles to get to work. ${ }^{44}$ To keep negotiations going and entertain the hope that they would lead to improvement in this situation, for example to the reopening of the border checkpoint in the region, district administrators had to obtain their superiors' approval repeatedly.

Trying to justify his intent to maintain working contacts with his colleagues in the eastern Eichsfeld districts despite the danger of being caught in political maneuvering by the GDR, Gleitze prepared a list of twenty-three items that required cross-border coordination. ${ }^{45}$ This list was produced for western consumption; he did not show it to his eastern colleagues. Accordingly, it did not include any item that might have been considered problematic in the west. On the contrary, in addition to many items that both sides were interested in, such as coordinating the containment of epidemics or fires, the list included items that interested the west. The first two items were access to the Duderstadt town forest east of the border and opening the border checkpoint between Gerblingerode and Teistungen. The list also included the mutual regulation of rivers and water sources, an important western interest, since the eastern part of the Eichsfeld was mountainous and lay upstream from the FRG part and as a result controlled most of the water sources. Permission was granted, and along with cross-border visits of choirs and football teams, the year following the Iseke celebration in Holungen also saw lively correspondence between the district administrations

\footnotetext{
${ }^{44}$ Extensive correspondence on both sides of the border deals with the effects on transportation. See, for example, Oberkreisdirektor Dud to Regierungspräsident Hildesheim, Dec. 4, 1953, KrAGö, LK DUD Nr. 61 (district administrator explaining to his superior that severing the border-crossing road passing through his district town had turned the town into a "dead corner" on the map); Besprechung über Bahnbuslinie 1200, Sept. 14, 1956, in StaADud, Fuhr 142 (administrators trying to convince representatives of the national railway company to reactivate a bus line connecting border villages). Kalikombinat Werra-Merkers, May 3, 1962, in BAB, DY 30 IV 2/12/73, 157-159 (changes in restricted zone regulations created transportation problems for this mining company). See also Gemeinde Wahlhausen to Ministerium d. Innern, Jan. 26, 1946, in KrAEich EA HIG Nr. 402/I (the damages to dairy farmers in frontier villages).

${ }^{45}$ After the event in Holungen, both Lower Saxon and federal offices wanted clarifications from Gleitze. They did not mind cultural exchanges but wanted to know the aim of meetings with local politicians that he planned. See memos in NLA-HStAH Nds. 50 Acc. 96/88 Nr. 705 and Gleitze's twenty-three-point document in KrArGö, LK DUD Nr. 61.
} 
in the eastern and western Eichsfeld and several cross-border visits by council members and district executives. ${ }^{46}$

\section{State Intervention and the Demise of Border-Crossing Contacts}

Though West German county and state authorities were always aware of existing contacts and negotiations and monitored them closely, they did not officially involve themselves. They sought to control the content of border-crossing talks without being in the room. When the district administrator from Duderstadt, Gleitze, met the county Minister President from Hildesheim, his superior, in October 1956, he found out that word of a planned visit of council members from the eastern part of the Eichsfeld region in the district of Duderstadt had already reached his superiors. The Minister President emphasized how important it would be to avoid any political issues during this visit. He thought it would be useful to open the first greeting of the visitors with a clear statement that "in no way is this a political visit with political discussions, but meant simply for the affirmation of good neighborly cooperation and the continuation of negotiations, bearing on completely apolitical local issues of local government." 47

Eastern state agencies also tried to control these negotiations, but they sought to direct them to lead to negotiation of more than just local, "technical" issues. They wanted to have these interactions lead to recognition — at least implicitly — of the GDR, and they also wanted to draw in higher-level state agencies. District officials from both sides of the border who participated in these meetings had to be attentive to the broader interests of their states and play by the rules set by their superiors if they were to be allowed to continue these negotiations. ${ }^{48}$

Back in Duderstadt after the meeting in Holungen, Gleitze did not waste time. On July 12, 1956, three days after returning, he began writing memos and making inquiries about the issues he discussed with his eastern colleagues, hoping to prove

\footnotetext{
${ }^{46}$ State agencies continued to supervise these contacts. The Lower Saxon Ministry of the Interior sent a division head (Ministerialrat) to question Gleitze on his interactions with eastern colleagues in February 1957. See Ministerialrat Nullmeyer to Oberkreisdirektor Gleitze, March 1, 1957, in KrArGö, LK DUD Nr. 61. For a list of the official cross-border meetings and events in the Eichsfeld in those years and a brief discussion of the optimistic atmosphere they brought, see Stadt Duderstadt, Die Grenze im Eichsfeld, 16-18.

${ }^{47}$ The district administrator transmitted these instructions to the official who was to greet the visitors. See Oberkreisdirektor Gleitze to Landrat Diedrich, Duderstadt, Oct. 6, 1956, KrArGö, LK DUD Nr. 61.

${ }^{48}$ For the eastern administrators, who were not elected but appointed by the ruling party, keeping to the lines dictated from above was crucial for keeping their jobs and their chances of advancing. In her dissertation, Edith Sheffer tells of the dismissal of an eastern district chairman who went too far in his negotiations with his western colleagues and promised progress on substantial issues. Sheffer, "Burned Bridge," 565-66. According to Jan Palmowski, residents of Holungen were convinced that the secretary of their district council had been fired because he had allowed the Heimatfest to take place. Palmowski, Inventing a Socialist Nation, 233-35.
} 
his intention to solve some of the problems they asked him about. It was not as easy as he had hoped it would be. One of the issues that the Worbis council members asked him to address, which Gleitze was happy to help with, was an exchange of land registry documents for plots around the border. In several areas along the border between the two districts, Soviet and British occupation forces swapped land in 1945. Consequently, many plots lay in the de facto jurisdictions of communities and districts that did not own the land registries of these plots. These communities, and both districts, thus could not charge taxes on these plots or perform and supervise legal actions pertaining to them. Gleitze wanted to deal right away with what appeared to him to be a simple matter. Within days he learned that it was not in his power.

The head of the land registry office in Duderstadt replied to his memo, saying that as of the previous year the Lower Saxon Minister of the Interior notified all land registry offices that his office would undertake all exchanges of documents with the GDR. ${ }^{49}$ Gleitze did not know that internal discussions between federal and state offices in the FRG and negotiations with the GDR on this issue had been going on since the late 1940s. Initially, all involved in the west - from the county, state, and federal levels— did not object to exchanging copies of land registry documents (keeping the originals so that in case of unification they would have the necessary documents). But as the internal correspondence developed, potential perils of such an exchange became clear. What if the GDR used the documents so acquired to disown private landowners and/ or to force collectivization of land? In addition, would surrendering copies of these documents to East German authorities not entail a formal recognition of the division of Germany and of the GDR? By 1956, federal and Lower Saxon state offices had decided that land registry documents should not be exchanged. Because they needed some legal documentation for routine administrative and economic practices, Lower Saxon authorities initiated the creation of new land registries. ${ }^{50}$ Gleitze was forced to backpedal from his promise to take care of this issue, but he did not give up his hope to promote local interests through negotiations with his colleagues from the east.

Similar news came from the eastern part of the Eichsfeld region quite quickly. Gleitze conveyed to his eastern interlocutors in Holungen the priority of discussing the reopening of the border checkpoint Gerblingerode-Teistungen. By the end of July he received an updated response on this question. The chief district

\footnotetext{
${ }^{49}$ Leiter d. Katasteramtes an d. Oberkreisdirektor Duderstadt, Aug. 22, 1956, KrArGö, LK DUD Nr. 61.

${ }^{50}$ The whole file NLA-HStAH Nds. 50 Acc. 96/88 Nr. 705 is dedicated to this issue, documenting more than a hundred pages of correspondence and memos from the years 1949-1958. See especially DDR Minister für Aufbau to Regierungspräsident Lüneburg, Nov. 2, 1950, Bundesminister für gesamtdeutsche Fragen to Nds. MP, Dec. 21, 1951, and Nds. Minister d. Justiz to Oberlandgerichtpräsident Celle, Jan. 4, 1957.
} 
administrator from Worbis, Werner Flächsig, wrote to him that he had the chance to raise this issue with his superiors and that they were very positively disposed toward finding a way to reopen the checkpoint. All that was required, he wrote, was for Gleitze to get his government to come to the discussion table and then official representatives of both states would be able to solve the problem. The least he expected of Gleitze was to have the district council officially call the federal government to take up discussion with the GDR on this issue. Gleitze replied politely a few weeks later, explaining that he could not discuss any "political" issues. Contacts between the governments in Bonn and Pankow were "a matter of highly political nature" (Angelegenheit hochpolitischer $A r t)$, so he must refrain from even discussing this option and obviously could not accommodate Flächsig's request. ${ }^{51}$ Though they allowed the contacts and negotiations, superior state agencies in both states had not changed their positions on the permitted contents for discussion and kept a close eye on frontier administrators, severely limiting the possible goals and achievements in these negotiations.

Other than creating a good atmosphere, the lively cultural exchanges, correspondences, and meetings following the celebration in Holungen resulted in only very modest levels of coordination. District administrators managed to find solutions only to those issues that could be solved via telephone calls between them or their aides, such as notifications in case of fire. But, tellingly, district administrators had not managed to establish permanent mechanisms to cooperate even in such cases. Coordination continued to depend on goodwill and personal commitment. And when the more complicated expectations of both sides were not fulfilled, goodwill dwindled.

The contradictions between the practical goals and the symbolic restrictions were too great to overcome. They came to the fore during and after an official visit of the Duderstadt district administrator and several council members to the neighboring districts of Worbis and Heiligenstadt in April 1957. At the press conference they held upon returning, the Duderstadt politicians spoke very highly of their hosts and of the prospects for cooperation. According to reports in western newspapers, the delegates also presented a list of issues that both sides agreed to address in future negotiations. The list, as published in the newspapers, included twenty-three items. It was identical to the list Gleitze had prepared for internal consumption. ${ }^{52}$ No agreement was reached with the eastern Eichsfeld representatives on this list or any other. Whatever Gleitze thought when he decided to make his list public - probably that it would help to make the public and his

\footnotetext{
${ }^{51}$ Flächsig to Gleitze, July 30, 1956, and Gleitze to Flächsig, Aug. 24, 1956, both in KrAGö, LK DUD, Nr. 61.

${ }^{52}$ The newspaper stories were cut and saved at the district archive in the same file with the correspondence. See KrArGö, LK DUD Nr. 61.
} 
superiors more favorably disposed toward his work- he must have realized also that it would cause problems with his eastern colleagues. ${ }^{53}$ The twentythree-item list had been prepared for western eyes and excluded issues that might have seemed "political" or undesirable to Gleitze's superiors. It did not include many items that the eastern negotiators repeatedly put on the table, such as exchanging delegations of high-ranking officials. District officials in the eastern part of the Eichsfeld region and their superiors in East Berlin read these reports carefully. ${ }^{54}$ Gleitze wrote to Flächsig to say that he should not take the reports too seriously. Flächsig replied that in his state, newspapers were taken very seriously, and he protested that the report was wrong to say that his council agreed with the western delegation on a list of issues to discuss. ${ }^{55}$ Gleitze argued that the journalists had misunderstood him, that they just counted issues he mentioned as potential things to talk about and made them into a title of a fictitious plan. He probably lied. The identical wording of all twenty-three articles to those in his original memo suggests that he not only dictated them to the journalists but probably handed out printed copies. This move is significant because it testifies to Gleitze's giving up on the chances of real progress. His priority of good public relations in the west over good terms with his eastern colleagues suggests that he sensed that a public-relations boost was the best thing he could still achieve in these negotiations. ${ }^{56}$

During 1958, the two districts maintained their contact only officially; no delegations crossed from side to side, and correspondence included mostly the subscriptions to local newspapers each district had arranged for the other. A clear indication that the GDR decided to give up on leveraging Eichsfeld culture for recognition came in the following year. The district of Worbis (in the eastern part of the Eichsfeld region) attempted repeatedly in 1959 to establish working relations with the border district of Eschwege in Hessen (west). Eschwege bordered on the Eichsfeld and on the district of Worbis from the southwest but did not share in the religion, traditions, or regional identification of the Eichsfeld. The district administrator in Eschwege rejected all attempts from Worbis to send an official delegation. Worbis did not relent and on two occasions

\footnotetext{
${ }^{53}$ Gleitze and his colleagues were probably under some pressure from journalists to justify the visit. When they crossed to the east, entry was denied to the journalists who accompanied the delegation, which did not help to make the media representatives favorable toward the whole affair.

${ }^{54}$ The story from the Südhanoversche Zeitung was typed word for word and saved in the district archive in the GDR part of the Eichsfeld. See KrArEich, EA HIG Nr. 402/I.

${ }^{55}$ See both letters in KrArGö, LK DUD Nr. 61.

${ }^{56}$ Oberkreisdirektor Gleitze to Vorsitz. d. Rat d. Kreises Flächsig, Jan. 15, 1958, in KrArGö, LK DUD Nr. 61. Edith Sheffer also suggests that press wars played an important part in border-crossing meetings. She convincingly shows that as long as western city officials hoped to achieve pragmatic progress in their negotiations, they were happy to keep them away from public view. When real progress was impossible, the border-crossing exchange turned into a press war. Sheffer, "Burned Bridge," 567-68.
} 
sent a delegation anyway. The delegates crossed the border as private individuals with permits and surprised the district administrator in his office. ${ }^{57}$ These tricks may have gained the GDR some marginal public-relations points for trying to establish cooperation between neighbors. But with no cultural exchange or shared heritage on which to base cooperation, such maneuvers could not be presented as anything other than trying to achieve political ends. None of those involved had any illusions about the chances of real border-crossing cooperation arising from this affair.

\section{Requiem: District Administrators Admit Failure of Border-Crossing Contacts}

In Duderstadt, Gleitze heard about the Worbis administrators' attempts to force Eschwege into official meetings and wrote to his colleague Flächsig. He wrote that he was sorry to have dropped the correspondence between them for a long time. After what had happened he thought that both of them needed to negotiate with their governments to prevent high politics from interfering with their quest to improve life in both their districts. ${ }^{58}$ The reply, which Flächsig drafted and probably never sent, is fascinating. It holds an analysis of the interactions of the previous years from the eastern side-the hopes, the chances, and the frustrations. It explains well why eastern administrators took up these negotiations and why and how they gave them up. Finally, it states the conditions for resuming negotiations. The draft opens with an admission that Flächsig, too, felt somewhat guilty that the correspondence between the two had lapsed. Then, for more than a page, he refuted Gleitze's version of why they had lost touch. $\mathrm{He}$ did not think that they should both negotiate with their governments, and he did not agree that they should prevent high politics from interfering in their negotiations. On the contrary, he thought that they could promote none of the issues that mattered to them without involving high politics. Their governments should speak to each other and then all the issues Gleitze defined as "technical" would be easy to solve on the local level. If the Federal Republic encountered such problems along its border with Switzerland, he wrote, it would not look to a district administrator to negotiate their resolution. It would send the Foreign Minister to negotiate with his colleague across the border because interstate negotiations were the only way to solve problems between states. "I know that you will answer me," he wrote, that "the government of the Federal Republic does not recognize the government of the GDR. Forgive me if I say

\footnotetext{
${ }^{57}$ Full reports by the participants of this delegation, including newspaper reports from the west, are in KrArEich, EA WBS Nr. 2248.

${ }^{58} \mathrm{I}$ did not find a copy of this letter. I deduced its content from the draft of the reply letter. See Entwurf: an Oberkreisdirektor Gleitze, Duderstadt in KrArEich, EA WBS Nr. 2248.
} 
so, but this is becoming ridiculous. After all, the GDR exists . . You cannot simply ignore a full-blown fact." 59

Nowhere was the truth of this statement as clear as it was along the interGerman border, where East German state agencies shaped crucial elements of everyday life. Relying on their influence over frontier realities, functionaries in the eastern part of the Eichsfeld region hoped that negotiating border issues would force the west to recognize the GDR and that western negotiators would understand they had to interact with the GDR if they wanted to improve life along the border. Eastern politicians accepted lower-level local meetings, assuming that the urgency of dealing with the situation along the border would draw in higher state agencies. They lost interest when they found that western insistence on exclusive representation was too rigid to allow such developments.

In the second part of the letter, Flächsig hinted that while he personally did not give up on the potential of negotiating with Gleitze, he had been ordered to change course and was not in a position to do anything about it. He apologized for the "strategic impoliteness" in going to Eschwege and not visiting Duderstadt as well, and wrote that he could offer no explanation for it. He repeated the same expression, "I can offer no explanation" (Ich kann keine Erklärung geben), several times, suggesting that higher authorities were involved. ${ }^{60}$ But, he wrote, none of this was intended to break off the existing relations with the district of Duderstadt. To demonstrate this, he invited Gleitze and a delegation from his district to visit Worbis again on the occasion of the tenth anniversary of the establishment of the German Democratic Republic. Flächsig thus made clear in this draft that the only way for him to get permission to pursue again the relations with colleagues from the western part of the Eichsfeld region was to base them on formal recognition of the GDR. By then, Flächsig understood Gleitze's position quite well. He realized that Gleitze would never accept this offer.

Even without receiving this letter, Gleitze must have known that the more ambitious part of his efforts had failed. Beyond celebrating regional traditions and dead poets, he had hoped to promote solutions for practical problems along

\footnotetext{
${ }^{59}$ Entwurf: an Oberkreisdirektor Gleitze, Duderstadt in KrArEich, EA WBS Nr. 2248. I have not found a final version of this letter in either the western or eastern archives, so I assume it was not sent. I think that it was too explicit regarding interventions from state agencies to pass censorship (see the next footnote). This makes the draft even more interesting in my view. Flächsig had not simply reiterated the formal version of his state (as in the reply regarding the border checkpoint quoted above), but invested in clarifying the points.

${ }^{60}$ For example, he wrote that he could not offer any explanation for the fact that Gleitze did not always receive the newspaper that Worbis sent him regularly. He wrote that he also did not regularly receive the paper sent to him from Duderstadt, especially during the time of the Geneva Conference. For that, too, he "could offer no explanation." Flächsig knew very well that GDR secret services, which monitored border-crossing mail, were responsible for the missing mail. He knew, too, that they would read this letter, as well.
} 
the border. He wanted to improve economic, ecological, and social conditions for frontier residents. He realized that this would entail recognition of some German authority east of the border and of its power to determine realities along the border. For that he needed authorization from his superiors in state and federal offices, but the authorization he received was limited and conditional. He was instructed to avoid all those things Flächsig had been ordered to achieve. But as long as Gleitze avoided "political issues," Flächsig avoided discussion of "technical issues." They ended up avoiding all issues other than cultural exchanges.

Following the construction of the Berlin Wall in August 1961, GDR state agencies built increasingly ominous and sophisticated barriers along the rural border as well. Triple fences, mines, and trip wires made illegal border crossing more difficult. These barriers had not interrupted regional, cross-border cooperation. State agencies' obsessive pursuit of their priorities in the battles over recognition of the GDR had already eliminated the potential to achieve valuable improvement in the frontier economy and daily life through cooperation by then. When eastern authorities realized that they could not use cultural exchange to achieve recognition, they put a stop to all official contacts.

\section{Exclusive Representation and Regional, Cross-Border Communities}

Caught in the web of restrictions woven by the war over exclusive representation, the two district heads had to give up their attempts to alleviate through cooperation some of the difficulties created by the inter-German border. Each side had to look away from the border, toward "its own" state agencies for solutions to these problems. Frontier residents realized gradually that the hope of turning the wheel back, enabling easy cross-border contacts, and renewing social and economic interaction was not realistic.

The determination of the West German government to ignore the GDR, together with the determination of the East German leadership to uphold its border regime and use it to win recognition, precluded local and regional crossborder cooperation for the first two decades of the inter-German border. Even relying on the thick cross-border infrastructure of long-standing relations, shared beliefs, kinship networks, and regional identification in the Eichsfeld, frontier administrations could not overcome the growing division produced by the battles over recognition. Cross-border connections on local levels never ceased completely, but the scope of what was possible to achieve through them, and consequently the drive to keep such channels open, narrowed significantly from the late 1950s. Eichsfelder realized that all border-related problems should be addressed to the governments of their respective states and would only be solved within the two separate territorial jurisdictions. The well in the eastern village of Brehme, which supplied water for Duderstadt since 1933, was neglected, and the water flow diminished over years of separation. Unable to coordinate 
maintenance works with eastern authorities, Duderstadt was forced to turn westward for help in finding alternative resources. By the late 1960s, the town was ready to replace all the water from Brehme with western sources. ${ }^{61}$ Even for their water, the two parts of the Eichsfeld were no longer inter-dependent.

As frontier residents' daily practices and needs connected them ever more tightly with eastern and western state organizations, their gaze turned gradually away from the border and toward their respective capitals; their regional, border-crossing communities and networks assumed an increasingly modest place in their experiences and identifications.

\section{Conclusion}

The western decision to isolate the German Democratic Republic internationally made recognition of the East German state a prominent conflict between the two German states. The smaller and weaker East German state sought ways to achieve international recognition and establish commercial and diplomatic relations with countries outside the Soviet Bloc. Its leaders understood that the key to this lay with Bonn. Border policy was one of the instruments East German decision makers applied in order to force Adenauer's government to recognize the GDR, at least de facto. East Germany's closing of the border in May 1952 turned the inter-German border into a constant reminder of the existence of the GDR and compelled many West Germans to deal directly with its authority. Frontier residents especially were faced with the impracticality of nonrecognition. Like Gleitze, many frontier residents and administrators expected western state agencies in those years to negotiate the reopening of checkpoints, allowing visits and trade, and much more. The story of the Gerblingerode-Teistungen checkpoint in the Eichsfeld was typical of the fate of such causes.

Both German states were unwilling to risk understandings that might appear to compromise their positions regarding recognition of the East German state in all but the rare extreme cases during the 1950s and 1960s. In the mid-1950s, party circles in East Germany harnessed regional identification and traditions in the Eichsfeld in an attempt to secure western recognition. Fearing exactly that, western state agencies instructed local politicians not to accept discussion of controversial issues and avoid at all cost any formal recognition of the negotiated problems as inter-state matters. Strictly keeping to this line, the western side exposed the real motivations behind the eastern initiative. When they understood that even implied recognition was not to be had, GDR party circles ordered the local representatives to withdraw from the negotiations altogether.

Frontier residents knew that many of their goals, such as good education, clean water, and preservation of regional traditions, could be at least partially achieved

${ }^{61}$ David Shears, The Ugly Frontier (New York: Knopf, 1970), 180-81. 
through stable cross-border coordination. They had been pursuing such cooperation across administrative and state borders for centuries previously. As shown in the example of Duderstadt, which relinquished land taxes and had its woods tended to in return, border-crossing social and economic networks of Eichsfeld residents were thick and effective in the postwar years. ${ }^{62}$

Priorities shaped by the battles over recognition of the GDR led eastern and western state agencies to undermine most initiatives for institutional border-crossing cooperation. To ensure local interests, frontier administrations had to adapt to the rules and comply with the demands of these new, western and eastern, state agencies. Frontier residents adjusted to the new rules, changing their practices to maximize opportunities and minimize risks they gave rise to. The accumulation of many such changes in orientation and shifts in practices worked to weaken cross-border religious, kinship, and economic networks, thus contributing to the process of German division.

Frontier residents and administrators had a much greater role in this process than scholars have assumed until recently. Edith Sheffer's work most clearly has returned the agency of "ordinary Germans" to the analysis of the Iron Curtain's evolution. This article suggests that we should interpret their agency cautiously. During the 1950s, there was room for initiative and action on both sides of the inter-German border. In the Eichsfeld and elsewhere, frontier residents initiated border-crossing contacts and found ways to persuade state agencies to allow them. But the initiative ran into the wall of state agencies' obsession with recognition. Many frontier residents expressed their wish to uphold their bordercrossing communities, demonstrating their still strong identification with these communities. But policies related to exclusive representation and the careful supervision enforcing them on frontier administrations denied frontier residents the prospect of fulfilling this wish. Local agency was important in shaping life along the border and the meanings attached to the border over time, but only within the limits imposed by state organizations.

A key stage in the creation and solidification of the Iron Curtain was the creation of physical, social, and cultural distance between former neighbors, friends, and relatives, and the gradual expansion of these distances. In the 1970s, the interGerman border had eventually come to be the effective division of a nation and a continent; ominous, controlled, and well guarded as its image suggests. Under Willy Brandt, the West German federal government gave up exclusive representation and signed an official treaty with the GDR in 1972. In the following year, the Eichsfeld checkpoint between Gerblingerode and Teistungen was finally

\footnotetext{
${ }^{62}$ This issue is dealt with in more depth in my dissertation. Schaefer, "Ironing the Curtain." See also Sagi Schaefer, "Border Land: Property Rights, Kinship, and the Emergence of the Inter-German Border in the Eichsfeld," in Praktiken der Differenz. Diasporakulturen in der Zeitgeschichte, ed. Miriam Rürup (Göttingen: Wallstein, 2009).
} 
reopened. It had been closed for more than two decades by then. In the meantime, division had become a stable experience. Regional and local problems were solved, festivals were celebrated, riverbeds cleared, land tilled, and produce bought and sold separately. East and west of the border, frontier residents had found ways to pursue their interests within the frameworks created by "their own" state agencies, and those states had become more "their own" in this process.

There is no telling how border-crossing networks and identifications would have fared had West Germany accepted the existence of a second German state in 1949. When it decided to drop exclusive representation, these networks were no longer as significant for the self-perception of most frontier residents as they had been two decades earlier. A generation grew by 1973 for which "the other side" was a foreign place. After the checkpoint was opened in the Eichsfeld, some western youth occasionally went across it for the cheaper beer and to enjoy the status of rich westerners. From the east only pensioners were allowed to cross, and they came to visit relatives and friends or do some shopping. Outside the family home, those who crossed in the 1970s and 1980s felt they were visiting a foreign land. ${ }^{63}$ They were indeed foreign despite their religion and accent. No longer part of the same viable regional community, they did not share experiences, expectations, orientations, or interests. They had become parts of two separate communities. The boundaries that emerged between them have proven since 1990 to be more resilient than the political and physical barriers that collapsed overnight.

Columbia University

\footnotetext{
${ }^{63}$ See, for example, the story of a boy from Duderstadt on his first visit to the GDR in Klaus Lüdge, "Reise vom Eichsfeld ins Eichsfeld 1971," in Erzählungen von der deutsch-deutsche Grenze, ed. Cornelia Röhlke (Efurt: Sutton Verlag, 2001), 84-85.
} 